\title{
Limestone Sedimentology of The Lengkong Formation at Neglasari District, Sukabumi-West Java, Based on Outcrop and Petrography
}

\author{
Muhammad Firdaus \\ Centre for Geological Survey, Geological Agency, \\ Ministry of Energy and Mineral Resources of The Republic of Indonesia \\ Diponegoro St. No.57, Kota Bandung, Jawa Barat 40122, Indonesia \\ *E-mail: muh.ahmad.firdaus@gmail.com
}

Article received: 8 July 2021, revised: 23 July 2021, accepted: 29 August 2021

DOI: $10.51835 /$ iagij.2021.1.2.36

\begin{abstract}
Research about Oligo-Miocene limestones in Java has always been interesting to study in order to understand the relationship between tectonic-volcanic, sedimentation, and petroleum potential. The Lengkong limestone formation is interesting to study especially its sedimentology aspects. There is no Scientific Publication about the Lengkong Formation which discusses detailed sedimentology aspects. Those aspects are important to modify the geological map, scale of 1: 50000 which was published by the ministry of energy and mineral resources. This research was conducted to determine the sedimentology process and development of a depositional environment of the Lengkong formation in the Cimapag River. The research area is located in Neglasari, Lengkong District, Sukabumi. The method used includes field surveys and laboratory analysis. A field survey embodies sedimentology data collection and rock sampling, which was then made into a detailed stratigraphic column. Rock samples were analyzed petrographically for 12 samples to determine microfacies. The results cover three limestone facies, namely wackestone, wackestone-packstone, and packstone facies. The sedimentation of the Lengkong Formation indicates a sea-level decrease of the Interbuild Basin Floor to Deep Marine Offreef.
\end{abstract}

Keywords: Lengkong formation, microfacies limestone, deep marine offreef

\section{INTRODUCTION}

Administratively, the research area is located in the Neglasari Village and its surroundings, Lengkong district, Sukabumi regency, West Java Province (Figure 1). The Oligo-Miocene limestone in Java is very interesting to be studied to understand the tectonic-volcanic relationship and limestone sedimentation on its petroleum potential. The Lengkong Formation belongs to one of the Miocene limestone formations. Until now there has been no detailed sedimentological research on this formation. This research was carried out to understand the sedimentological processes and the development of the limestone depositional environment of the Lengkong Formation in the Cimapag River.
The results of this study are used to update the geological map of 1:250.000 scale and as the main basis to modify the geological map with a scale of 1:50.000 as published by the Geological Agency, Ministry of Energy and Mineral Resources.

\section{REGIONAL GEOLOGY}

The discussion of regional geology in the research area has been discussed [1]. The research area is part of the Bogor Basin Mandala which is characterized by sedimentation of gravity flow and undergoes changes ranging from the deep sea to shallow sea in the Tertiary-Quaternary period. Limestone unit in the study area which is part of the Lengkong Formation developed during 
the middle to late Miocene (Figure 2). During middle Miocene, the limestones in SW and Central Java were deposited above the OligoMiocene Volcanic rocks of the Jampang and bon Formations [2] (Figure 4). These units comprise coralline and algal limestones and their associated slope deposits [2]. Limestone sedimentation grew rapidly along with the cessation of Jampang volcanic rock series in southern West Java [3]. The Lengkong Formation or what is called "The Lengkong Formation reef limestones" consists of a thick coralline limestone, porous Globigerina limestone, and develops into platy coral limestones to the east.

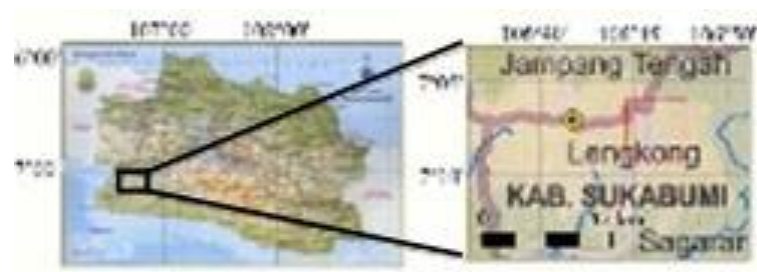

Research Area

a.

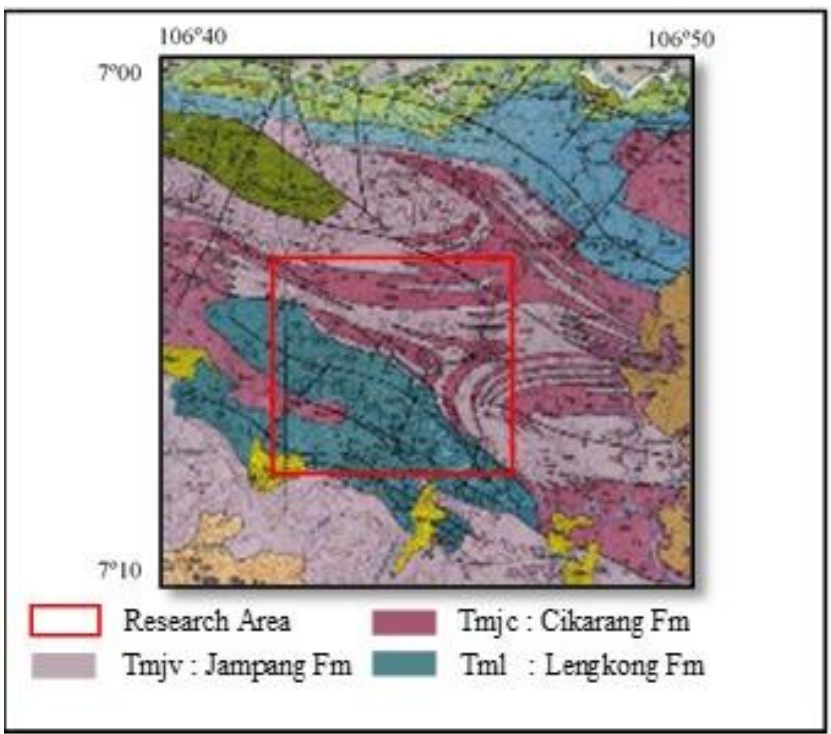

Figure 1. (a) Location of the study area and (b) Geological map of the Jambang and Balekambang [4].

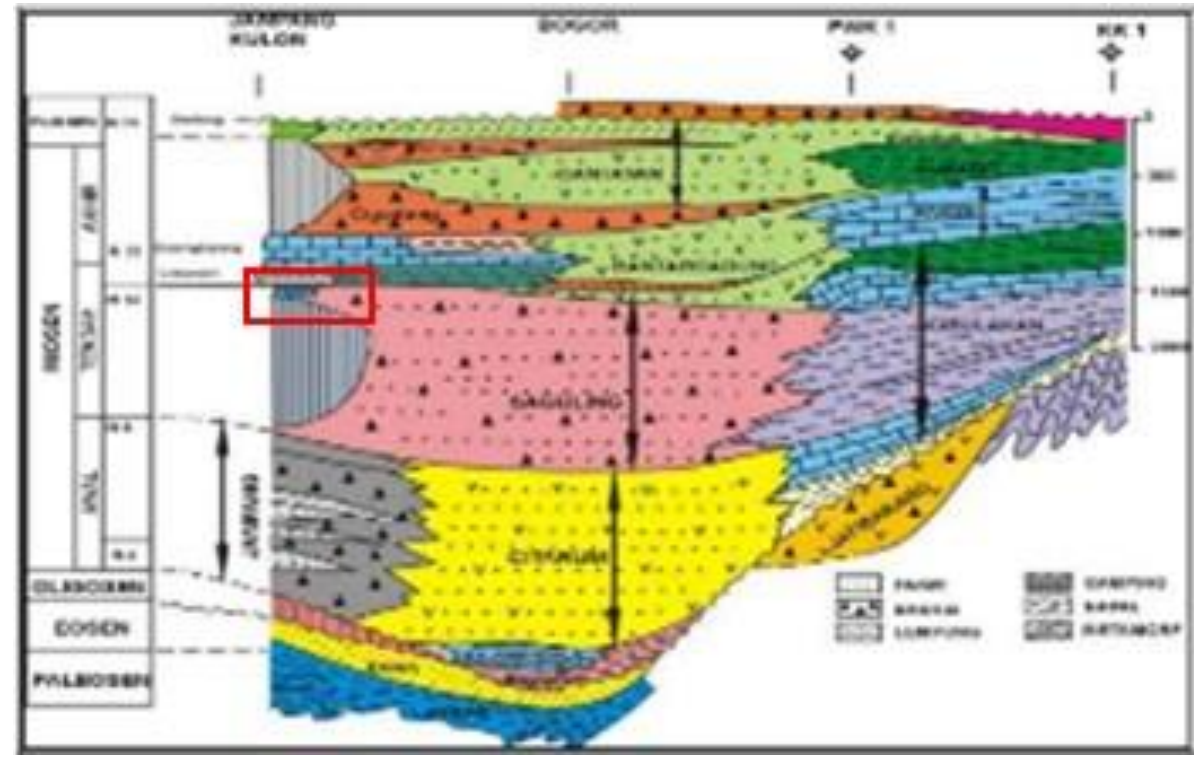

Figure 2. The restored stratigraphic cross-section of north-south West Java [1]. The middle Miocene Lengkong formation is showed by red circle. 


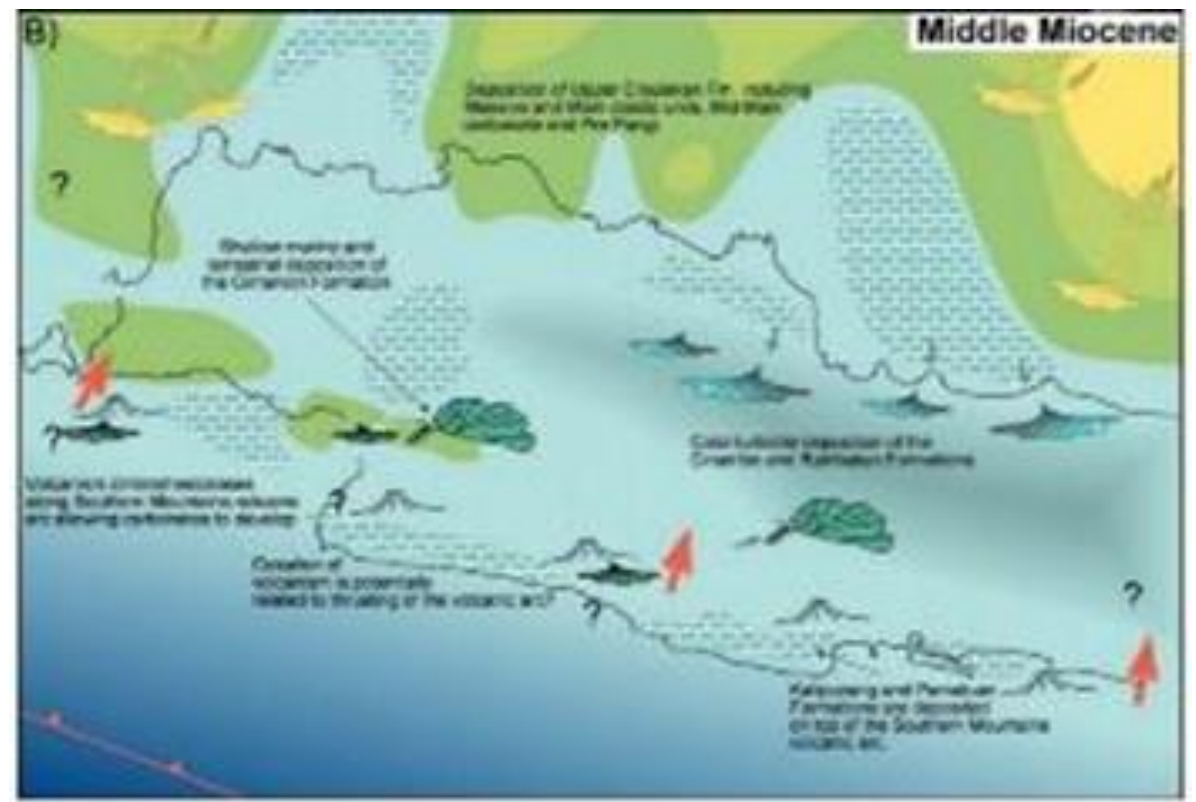

Figure 3. Middle Miocene paleogeography of West Java during Middle Miocene time, limestones in SW and Central Java lie unconformably above the Oligo-Miocene volcanic rocks of the Jampang and Gabon formation, which suggest the termination period of volcanic activity [2].

\section{DATA AND METHOD}

The research area is located along the Cimapag river in the Neglasari Village, from upstream to downstream. There are two stages in this research, namely field survey and laboratory analysis. In initial stage includes data collection, particularly for sedimentological data. At this stage, detailed trajectories and the vertical rock profiles were made from the oldest to youngest succession. The following stages are outcrop observations, field sketching, measuring detailed stratigraphic sections and rock descriptions, including rock properties, such as sedimentary structures and geological structure. These data were then made as measured stratigraphic column equipped with the characteristics of each layer.

For laboratory analysis, a total of 12 rock samples were subjected to petrography analysis to observe the visual characteristics of texture, fabric, grain morphology, minerals, bioclastic composition, the matrix for determining rock units and determining the type of microfacies based on thin limestone incisions. The results of the field survey and laboratory analysis were used to assist the analysis and interpret the sedimentological aspects of the limestone. The study applies limestone classification from Dunham [5] and Embry \& Klovan [6].

The results were used to determine microfacies as the basic interpretation of the depositional environment. The microfacies assemblage was determined according to Flugel (subsequently was abbreviated as SMF) [7] and facies belts according to Wilson (referred to FZ) [8]. As reference, the interpretation of the depositional environment refers to the classification of Towers (1999) by considering the type of bioclastic.

\section{RESULTS AND DISCUSSION Outcrop Appearance}

Geomorphologically, the study area is a synclinal valley with run-off axis trending relatively northwest-southeast as notified by tight contour. Based on the slope, this area is classified as a steep area [9]. According to the field observation, the limestone of the 
Lengkong Formation in the Cimapag river and its surrounding is bioclastic limestone, with a thickness of about $79 \mathrm{~m}$ (Figure 4, 5, 6, and 7).

The stratigraphic sequence of the studied formation begins with the presence of poorly layered Wackestone with a thickness of about $23 \mathrm{~m}$. These rocks conformably overlay tuff layers of the Jampang Formation. Massive wackestone has the characteristics of cream color in fresh conditions and yellowish cream in weathered conditions, mud supported, hards, and comprised of predominant benthonic foraminifera (Figure 4 and 5).

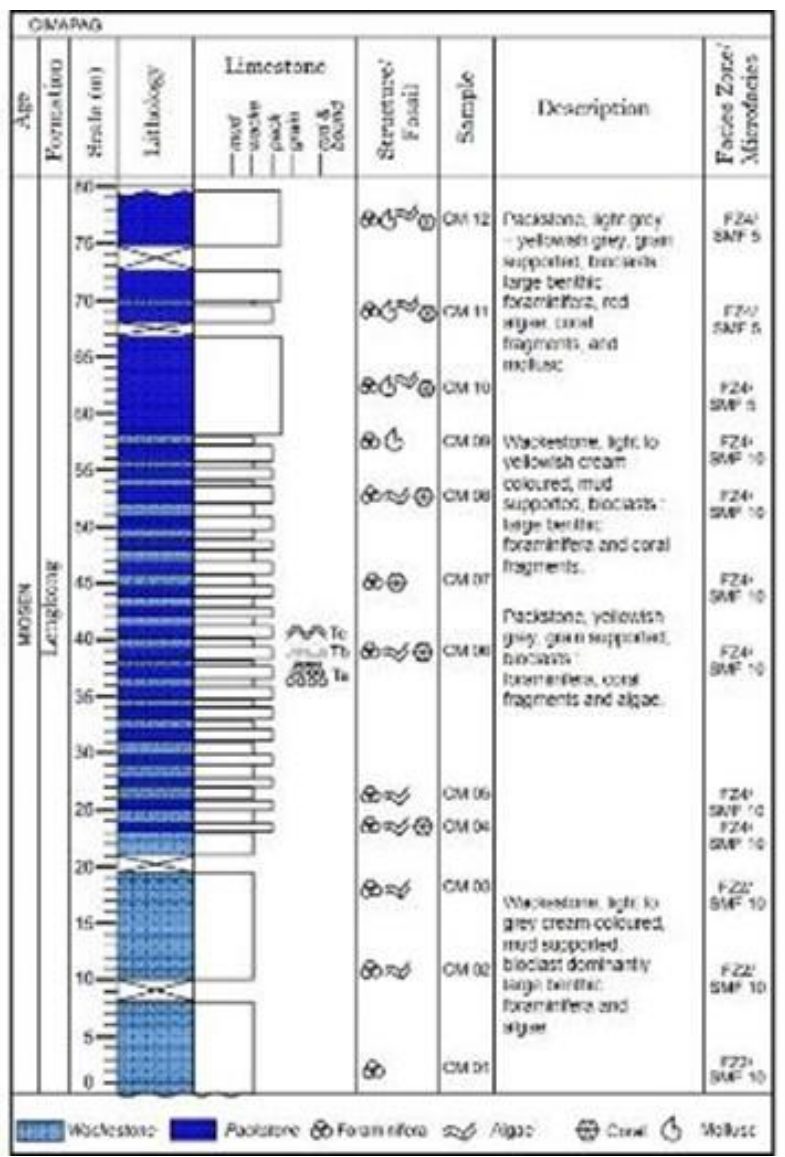

Figure 4. Stratigraphic column of the Lengkong formation in Cimapag river, Sukabumi, West Java.

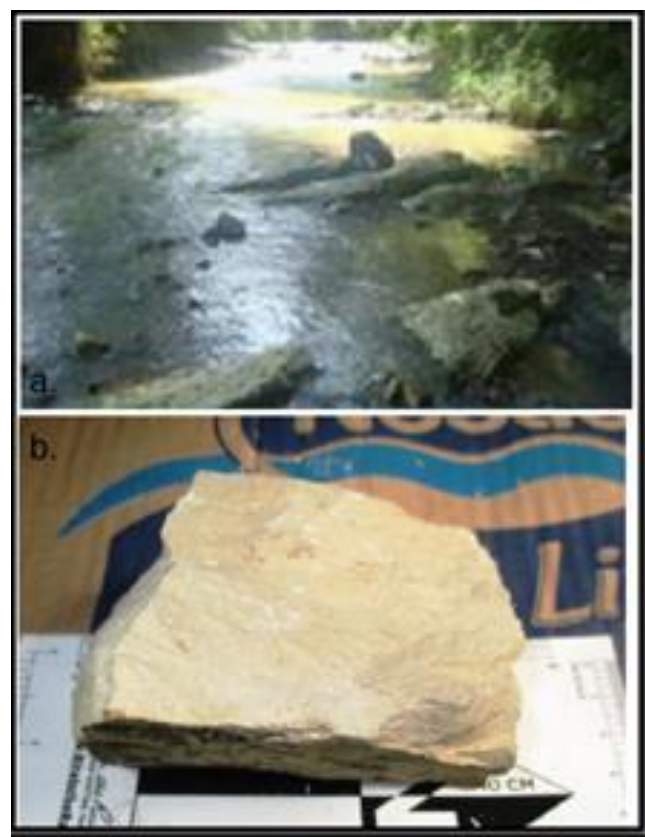

Figure 5. a) Wackestone outcrop appearance at station CM 9, b) Handspecimen of wackestone

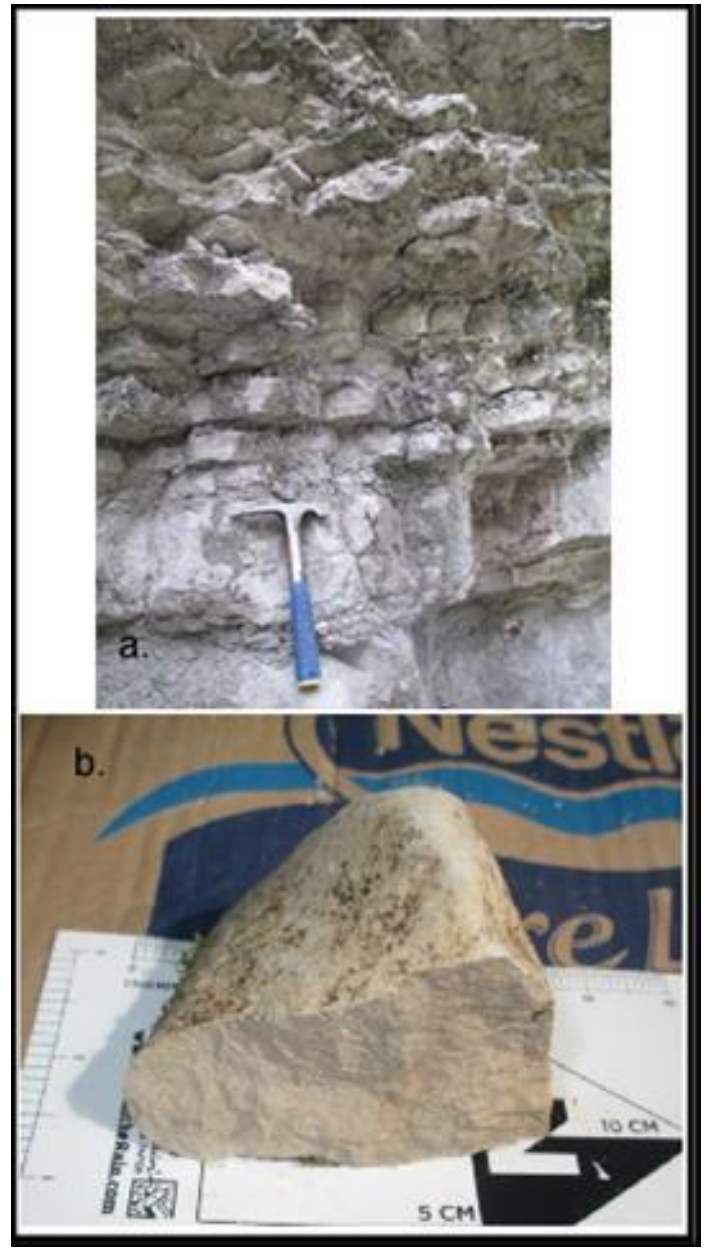

Figure 6. a) Intercalation wackestone and packstone outcrop appearance, b) Hand specimen of packstone. 


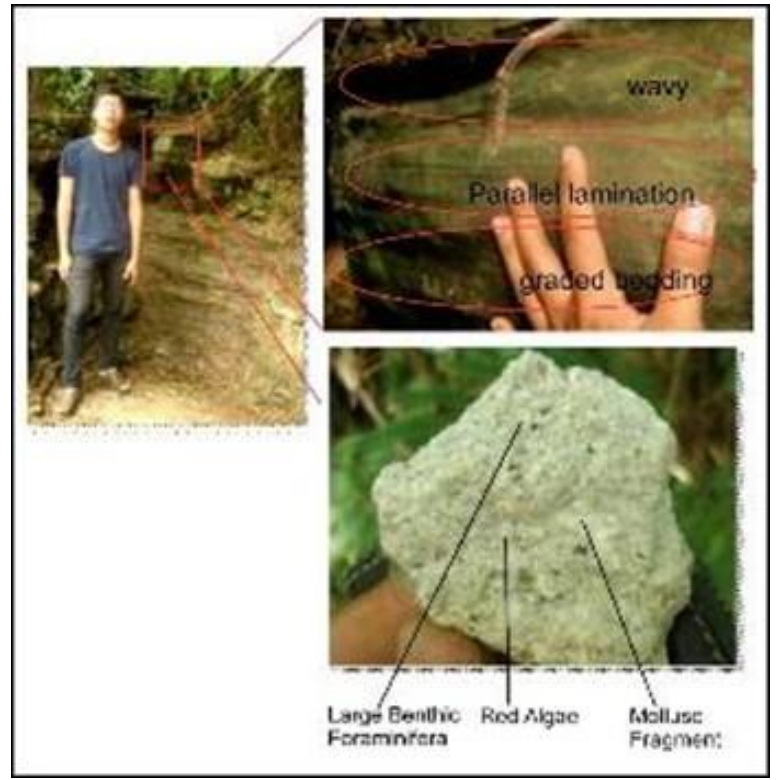

Figure 7. a) Packstone outcrop appearance, b) Sedimentary structures show a Bouma Sequence, c) Hand specimens of limestone packstone with dominantly large benthic foraminifera.

\section{Petrography}

A total of 12 (twelve) limestone samples that make up the Lengkong Formation at the Cimapag River location have been taken and petrographic tests were carried out using Dunham's classification reference [5]. The results of petrographic testing (Table 1) show that at the research location there are several limestone facies, namely foraminifera wackestone, wackestone-packstone, and large benthonic foraminifera packstone. The foram fossil recognition approach refers to the classification according to Lunt [10].
Wackestone has a bioclastic texture, dominated by mud, with granules present in the form of bioclasts, especially large bentonic foraminifers and a few small foraminifera and algae (Figure 8). The large bentonic foraminifera that appear include Lepydocyclina sp. Pellets and intraclasts are present very rarely with local spread.

The wackestone unit has a bioclastic texture and has recrystallized quite strongly. The carbonate granules comprise the bioclasts of large foraminifera fossil fragments and a few mollusks shell fragments. The packstone unit as the dominant layer in this facies has a bioclastic texture, with the bioclastic component dominated by large bentonic foraminifera. Besides that, algae is also present in the form of body fragments (Figure 9).

Large Benthonic Foraminifera Packstone facies has a bioclastic texture with granules dominated by large bentonic foraminifera (Figure 10) such as Lepydocyclina sp., Miogypsina sp., And Cyclocypeus sp. Molluscs are present as the second largest bioclast, mostly in the form of shell fragments. Longshaped algae are present as subsequent bioclasts. Molluscs and some algae have undergone micritization. The matrix is cloudy brown and has been converted to micrite. 
Table 1. Summary of the petrography analysis of limestone from the Lengkong formation in the Cimapag River and its surroundings, Sukabumi, West Java.

\begin{tabular}{|c|c|c|c|c|c|c|c|c|c|c|c|c|}
\hline Description & $\begin{array}{c}\mathrm{CM} \\
1\end{array}$ & $\begin{array}{c}\mathrm{CM} \\
2\end{array}$ & $\begin{array}{c}\mathbf{C M} \\
\mathbf{3}\end{array}$ & $\begin{array}{c}\mathrm{CM} \\
4\end{array}$ & $\begin{array}{c}\mathbf{C M} \\
5\end{array}$ & $\begin{array}{c}\text { CM } \\
6\end{array}$ & $\begin{array}{c}\text { CM } \\
7\end{array}$ & $\begin{array}{c}\text { CM } \\
8\end{array}$ & $\begin{array}{c}\text { CM } \\
9\end{array}$ & $\begin{array}{c}\text { CM } \\
10\end{array}$ & $\begin{array}{c}\mathrm{CM} \\
11\end{array}$ & $\begin{array}{c}\mathrm{CM} \\
12\end{array}$ \\
\hline Texture & bf & bf & bf & bf & bf & bf & bf & bf & bf & bf & bf & bf \\
\hline Sorting & $\mathrm{p}$ & $\mathrm{p}$ & $\mathrm{p}$ & $\mathrm{p}$ & $\mathrm{p}$ & $\mathrm{p}$ & $\mathrm{p}$ & $\mathrm{p}$ & $\mathrm{p}$ & $\mathrm{p}$ & $\mathrm{p}$ & $\mathrm{p}$ \\
\hline Fabric & o & o & o & o & o & o & o & o & o & o & o & o \\
\hline $\begin{array}{l}\text { Grain Size } \\
\quad(\mathrm{mm})\end{array}$ & $\begin{array}{c}0,05- \\
0,3\end{array}$ & $\begin{array}{c}0,05- \\
0,4\end{array}$ & $\begin{array}{c}0,1- \\
0,3\end{array}$ & $0,1-2,6$ & $\begin{array}{l}0,05- \\
0,25\end{array}$ & $\begin{array}{l}0,2- \\
2,5\end{array}$ & $0,1-0,3$ & $0,1-3$ & $\begin{array}{c}0,05- \\
0,2\end{array}$ & $0,2-3,5$ & $0,1-4$ & $0,2-3,2$ \\
\hline Roundness & sa-sr & sa-sr & sa-sr & sa-sr & sa-sr & sa-sr & sa-sr & sa-sr & sa-sr & sa-sr & sa-sr & sa-sr \\
\hline Grain contact & $\mathrm{f}$ & $\mathrm{f}$ & $\mathrm{f}$ & $\mathrm{p}, \mathrm{l}, \mathrm{c}$ & $\mathrm{f}$ & $\mathrm{p}, 1, \mathrm{c}$ & $\mathrm{f}$ & $\mathrm{p}, 1, \mathrm{c}$ & $\mathrm{f}$ & $\mathrm{p}, 1, \mathrm{c}$ & $\mathrm{p}, 1, \mathrm{c}$ & $\mathrm{p}, 1, \mathrm{c}$ \\
\hline \multicolumn{13}{|c|}{$\begin{array}{c}\% \text { Component } \\
\text { Carbonate Grain }\end{array}$} \\
\hline Bioclast & 15 & 13 & 18 & 35 & 12 & 40 & 20 & 45 & 18 & 38 & 42 & 40 \\
\hline $\begin{array}{l}\text { Intraclast/ } \\
\text { Extraclast }\end{array}$ & - & - & - & - & - & - & - & - & - & - & - & - \\
\hline \multicolumn{13}{|c|}{ Terrigenious Grain } \\
\hline Qz & - & - & - & - & - & 0,5 & - & - & - & - & - & 1 \\
\hline Feldspar & - & - & - & - & - & & - & - & - & - & - & - \\
\hline Lithic & - & - & - & - & - & 1 & - & - & - & 1 & 1 & 2 \\
\hline Others & - & - & - & - & - & - & - & - & - & - & - & - \\
\hline \multicolumn{13}{|c|}{ Matrix } \\
\hline Lime Mud & 72 & 76 & 74,5 & 45,5 & 78 & 40,5 & 71 & 35 & 74 & 44 & 40 & 37 \\
\hline Clay Mineral & - & - & - & - & - & - & - & - & - & - & - & - \\
\hline \multicolumn{13}{|c|}{ Cement } \\
\hline Orthosparit & 12 & 9,5 & 7 & 16 & 9 & 13,5 & 8 & 18 & 7,5 & 14 & 14 & 16 \\
\hline Fe Oxide & - & 0,5 & - & 1 & - & 0,5 & 0,5 & - & - & - & - & 1 \\
\hline \multicolumn{13}{|c|}{ Porosity } \\
\hline $\begin{array}{l}\text { Intra-Inter } \\
\text { particle }\end{array}$ & 0,5 & 2 & 0,5 & 3 & 3 & 2 & 0,5 & 2 & 0,5 & 3 & 3 & 2 \\
\hline Other Primary & - & - & - & - & - & & - & - & - & - & - & \\
\hline Vuggy & - & - & - & - & - & 1 & - & - & - & - & - & 1 \\
\hline Rock Name & $\mathrm{W}$ & $\mathrm{W}$ & $\mathrm{W}$ & $\mathrm{P}$ & $\mathrm{W}$ & $\mathrm{P}$ & $\mathrm{W}$ & $\mathrm{P}$ & $\mathrm{W}$ & $\mathrm{P}$ & $\mathrm{P}$ & $\mathrm{P}$ \\
\hline FZ/SMF & $2 / 10$ & $2 / 10$ & $2 / 10$ & $4 / 10$ & $4 / 10$ & $4 / 10$ & $4 / 10$ & $4 / 10$ & $4 / 10$ & $4 / 5$ & $4 / 5$ & $4 / 5$ \\
\hline Bioclasts & $\mathrm{F}$ & $\mathrm{F}, \mathrm{A}$ & $\mathrm{F}, \mathrm{A}$ & $\mathrm{F}, \mathrm{A}, \mathrm{C}$ & $\mathrm{F}, \mathrm{A}$ & $\begin{array}{l}\mathrm{F}, \mathrm{A} \\
\mathrm{C}\end{array}$ & $\mathrm{F}, \mathrm{A}$ & $\mathrm{F}, \mathrm{A}, \mathrm{C}$ & $\mathrm{F}, \mathrm{M}$ & $\begin{array}{l}\mathrm{F}, \mathrm{A} \\
\mathrm{C}, \mathrm{M}\end{array}$ & $\mathrm{F}, \mathrm{A}, \mathrm{C}, \mathrm{M}$ & $\mathrm{F}, \mathrm{A}, \mathrm{C}, \mathrm{M}$ \\
\hline
\end{tabular}

Texture: (bf) bioclastic fragment; (cf); clastic fragment; (nc) non mollusc. Sorting: (p) poor; (vp) very poor. Fabric: (c) close; (o) open. Roundness: (a) angular; (sa) sub-angular; (sr) sub-rounded; (r) rounded. Grain-Contact: (f) floating; (p) point); (l) long; (c) concave-convex; (s) sturred. Rock Name: (W) Wackestone; (P) Packstone. Microfacies: (SM) Standard Microfacies [7]; (FZ) Facies Zone [8]. Bioclast: (F) Foraminifera; (A) Algae; (C) Coral; (M) Mollusc 


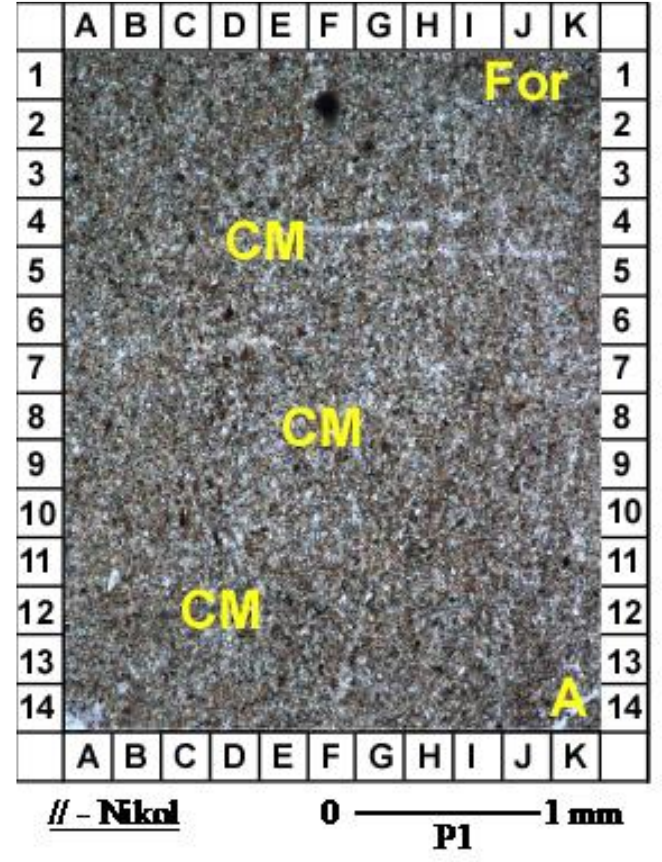

Figure 8. Wackestone, bioclastic texture, mud supported, poor sorted, open fabric, $13 \%$ grain component consisting of large and small foraminifera (For) $(10 \%)$ and Algae (A) (3\%). $76 \%$ micrite (CM) matrix, $10 \%$ sparry calcite cement, and $1 \%$ porosity. (CM 02).

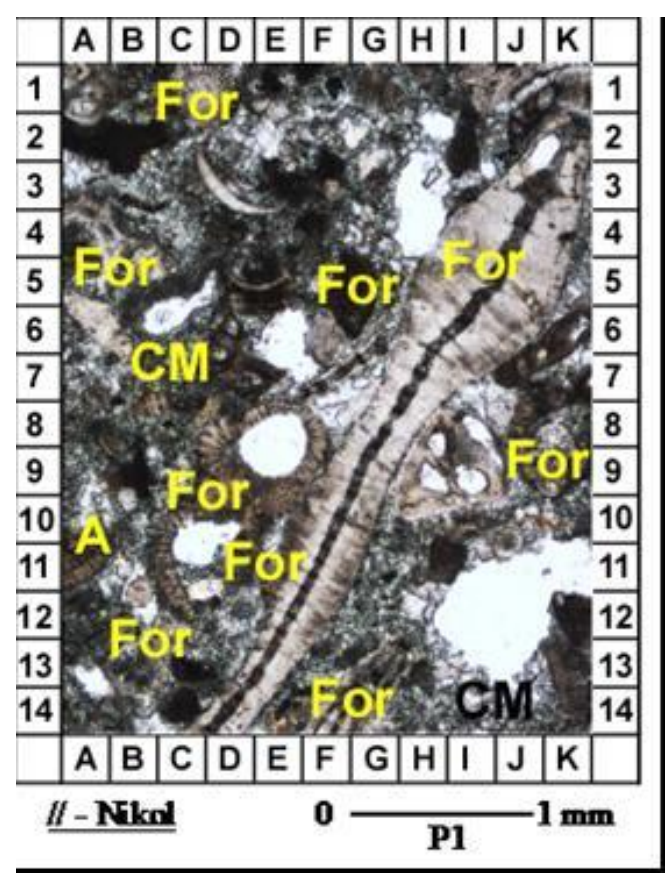

Figure 9. Packstone, bioclastic texture, grain supported, poorly sorting, open fabric, $40 \%$ grain component consisting of large and small foraminifera (For) and algae (A). $42 \%$ micrite matrix and $14 \%$ sparry calcite cement, and $4 \%$ porosity (CM06).

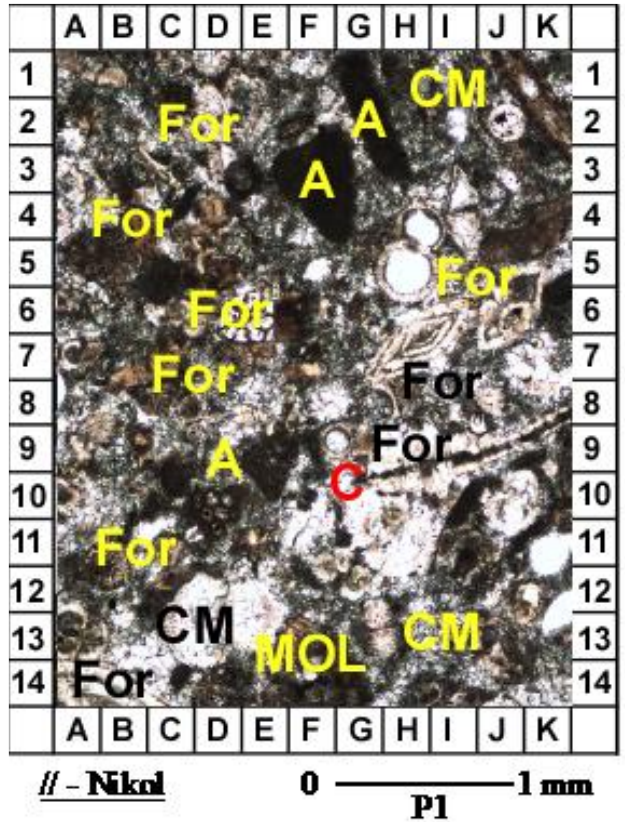

Figure 10. Packstone, bioclastic texture, grain supported, poor sorting, open fabric, $42 \%$ grain component consisting of large and small foraminifera (For), Algae (A), coral (C), and molluscs (Mol). Micrite matrix (CM) $40 \%$ and $15 \%$ sparry calcite and $3 \%$ porosity (CM 11).

\section{The development of the depositional environment}

The development of the depositional environment of the Lengkong formation generally shows a phase of sea-level drop. This is indicated by changes in facies and deposition area from the bottom to the top microfacies. The lowermost part of the Lengkong formation consists of wackestone facies which was deposited in the boundary area of the interbuild basin floor to deep marine off-reef (equivalent to a depth of 60$120 \mathrm{~m}$ ) (Figure 11). The next microfacies, the wackestone-packstone, was deposited in the deep marine offreef area (equivalent to a depth of 60-100 m) (Figure 12). The lowering of sea level took place above the top of microfacies, namely the packstone microfacies which was deposited in the deep marine off-reef area (equivalent to a depth of 60-90 m) which is closer to the slope (Figure 13). The 
sedimentary structures in the middle and upper part of this formation are graded bedding (ta), parallel lamination (tb) and wavy (tc) with successive positions (Bouma sequence) indicate that the depositional process is influenced by gravity mass flow. This interpretation supports the results of the analysis of the depositional environment as the gravity mass flow occurs in the slope area, while the depositional area of this formation is close to the slope.

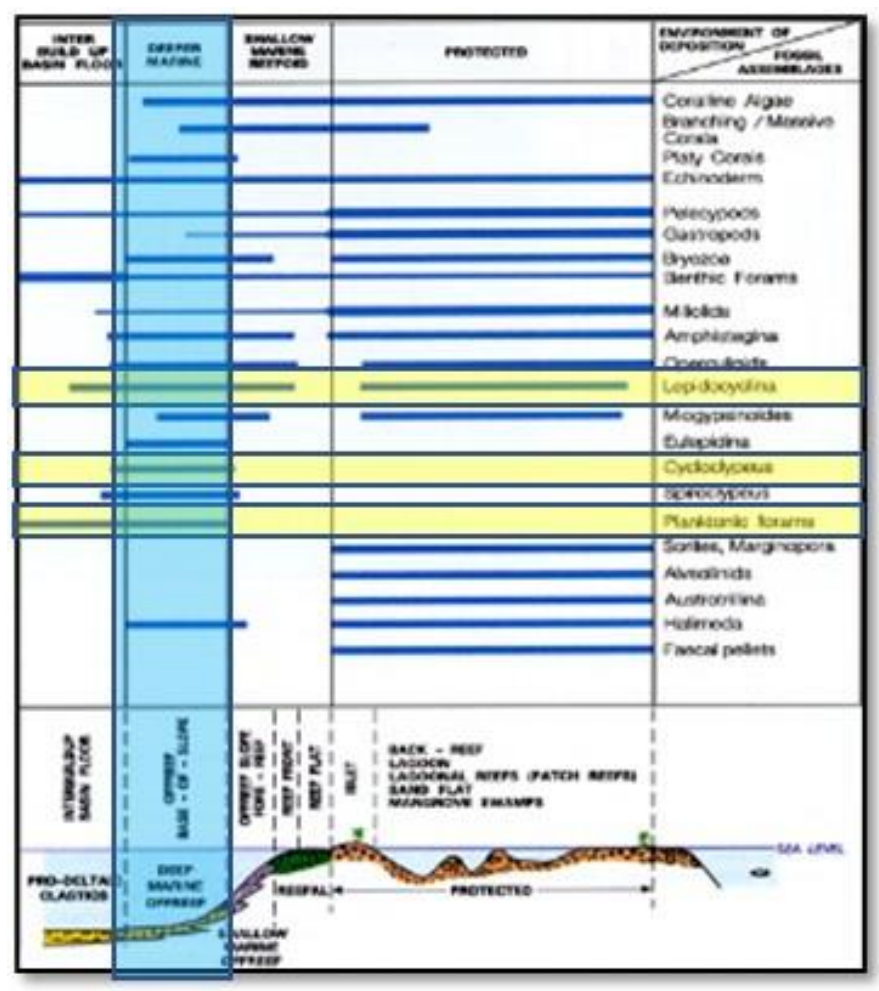

Figure 11. Based biofacies classification [11], the wackestone facies is deposited in the interbuild up basin floor deep marine off-reef marine environment (60-120 meters below sea level). 


\section{IAGI Journal}

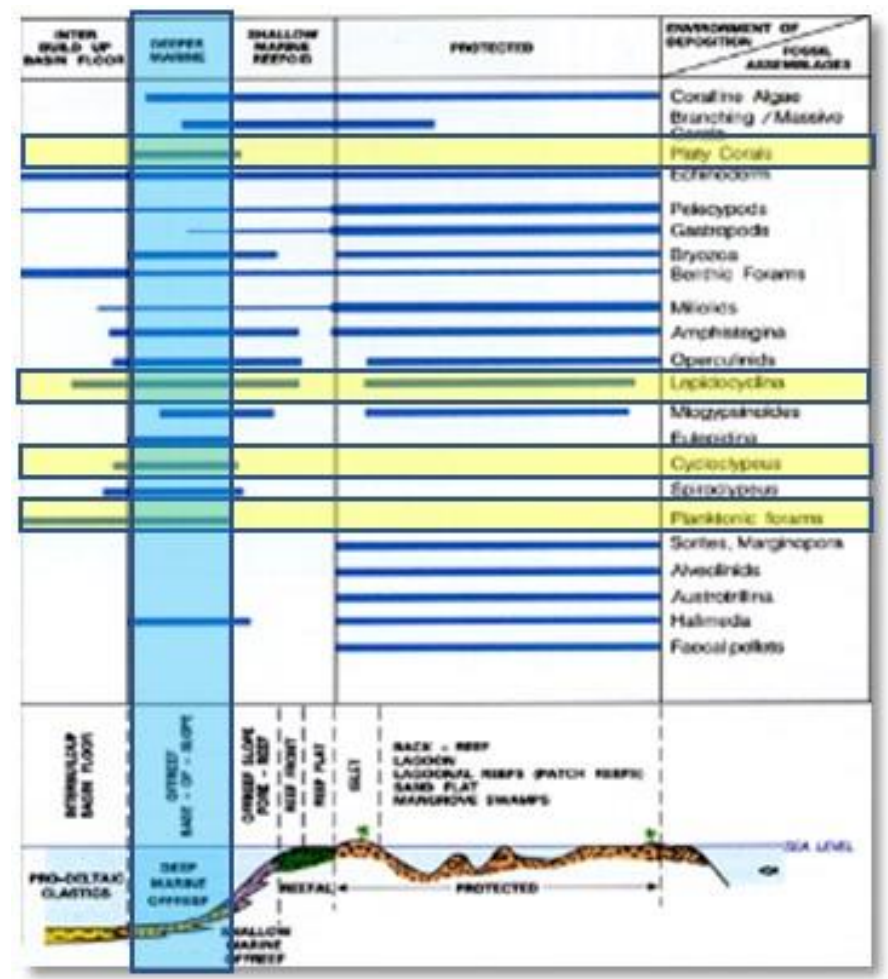

Figure 12. Based on biofacies classification [11], the wackestone - packstone facies is deposited in the deep marine off-reef area (60-100 meters below sea level).

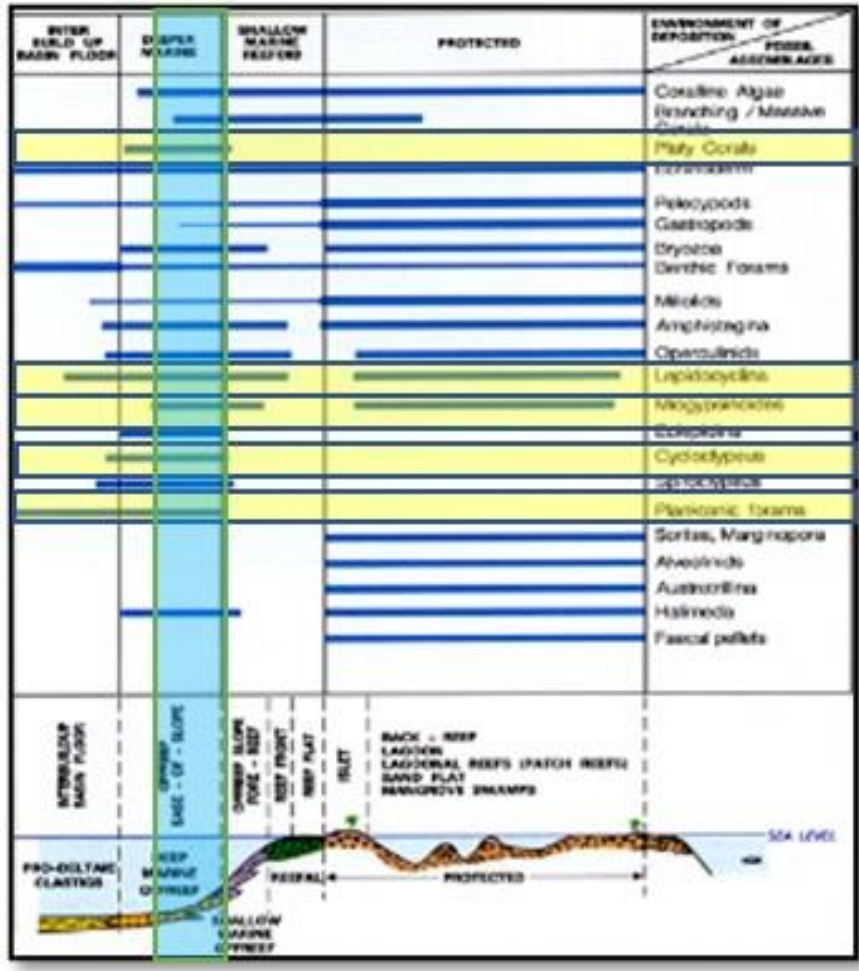

Figure 13. Based on biofacies classification [11], the packstone facies is deposited in the deep marine off-reef area (60-90 meters below sea level). 


\section{CONCLUSION}

Lengkong Limestone unit in the Cimapag River is composed of wackestone, wackepackstone, and packstone with a total thickness of approximately $79 \mathrm{~m}$. The depositional setting of this unit represents a degression of sea level from interbuild up basin floor to deep marine off-reef (equivalent to a depth of $60-120 \mathrm{~m}$ ).

\section{REFERENCES}

1. Martodjojo, S. Evolusi Cekungan Bogor, Jawa Barat, Institute Technology Bandung, 1984.

2. Clements, B.; Hall, R. Cretaceous to Late Miocene Stratigraphic and Tectonic Evolution of West Java. In Proceedings of the Proceedings of Indonesian Petroleum Association; 2007.

3. Satyana, A.H. Oligo-Miocene Carbonates of Java, Indonesia, Tectonic-Volcanic Setting and Petroleum Implications. In Proceedings of the Proceedings of Indonesian Petroleum Association; 2005.
4. Sukamto Geological Map of the Jambang and Balekambang Quadrangel; 1979.

5. Dunham, R.J. Classification of Carbonate Rocks According to Depositional Texture. In Proceedings of the American Association of Petroleum Geology Memoir; 1962; pp. 108-121.

6. Embry, A.F.; Klovan, J.E. A Late Devonian reef tract on North-Eastern Banks Island, North West Territory. Bull. Can. Pet. Geol. 1971, 19, 730-781.

7. Flugel, E. Microfacies of Carbonate Rocks: Analysis, Interpretation and Application.; Springer-Verlag Inc.Berlin, Heidelberg: Newyork, 2004.

8. Wilson, J.L. Carbonate Facies in Geologic History; Springer-Verlag, Newyork, Heidelberg: Berlin, 1975.

9. van Zuidam, R.A. Guide to Geomorphic Aerial Photographic Interpretation and Mapping; ITC: Enschede, 1983.

10. Lunt, P. Larger Foraminifera and Biostratigraphy in Oligo-Miocene; Carbonate Rich Period in SE Asia with Many Oil and Gas Reservoirs; 2004;

11. Petronas Research and Scientific Services The Petroleum Geology and Resources of Malaysia; 1999. 